\title{
PENGARUH METODE PEMBELAJARAN DAN POWER LENGAN TERHADAP HASIL BELAJAR LEMPAR LEMBING
}

\author{
Risma Horjani Bounty Napitupulu ${ }^{1}$ dan Binsar Panjaitan ${ }^{2}$ \\ SMP Negeri 1 Porsea ${ }^{1}$ dan Universitas Negeri Medan ${ }^{2}$ \\ rismahbnapitupulu@yahoo.com ${ }^{l}$
}

\begin{abstract}
Abstrak: Penelitian ini bertujuan untuk, mengetahui hasil belajar lempar lembing siswa yang dibelajarkan dengan metode bermain dan metode demonstrasi, mengetahui hasil belajar lempar lembing siswa yang memiliki power lengan kuat dan power lengan lemah, dan mengetahui adanya interaksi antara metode pembelajaran, power lengan terhadap hasil belajar lempar lembing siswa. Metode penelitian menggunakan metode eksperimen dengan rancangan quasi eksperimen desain faktorial $2 \times 2$. Teknik analisis data yang digunakan adalah ANAVA dua jalur dengan taraf signifikan $\alpha=0,05$ dan dilanjutkan dengan uji scheffe, yang sebelumnya dilakukan uji persyaratan analisis yaitu uji normalitas dan uji homogenitas. Hasil penelitian menunjukkan; hasil keterampilan lempar lembing yang dibelajarkan dengan metode bermain lebih tinggi dari pada dengan metode demonstrasi dengan Fh 4,01 > Ft 3,98. hasil keterampilan lempar lembing yang memiliki power lengan kuat lebih tinggi dari pada power lengan lemah Fh 10,86 > Ft 3,98. Dan Adanya interaksi antara metode pembelajaran dan power lengan terhadap hasil belajar lempar lembing Fh 5,14> Ft 3,98.
\end{abstract}

Kata Kunci: metode pembelajaran, power lengan, hasil belajar lempar lembing

Abstract: This study aims to; determine learning outcomes javelin students that learned the method of play and method of demonstration, determine learning outcomes javelin students who have power strong arm and the power arm is weak, and determine the interaction between learning method, power arm javelin on learning outcomes of students. The research method using an experimental method using quasi-experimental design of $2 \times 2$ factorial design data analysis technique used was ANOVA two lanes with significance level $\alpha=0.05$ and was followed by Scheffe test, which previously conducted test requirements analysis is the normality test and homogeneity test, The results showed; results javelin skills that learned with the method of play is higher than on the method of demonstration by Fc $4.01>3.98$ Ft. the results javelin skills that have a strong arm power higher than the power arm is weak Fc $10.86>F t$ 3.98. and The interaction between learning method and power arm towards learning outcomes javelin Fc $5.14>$ Ft 3.98.

Keywords: teaching methods, power arms, learning outcomes javelin

\section{PENDAHULUAN}

Lempar lembing adalah salah satu cabang olahraga Atletik nomor lempar. Di dalam olahraga lempar lembing terdapat 2 macam gaya, yaitu gaya jengket (hop style) dan gaya langkah silang (cross). Lempar lembing gaya jengket (hop style) lebih mudah dilakukan karena untuk membentuk gaya hop cukup satu kali berjingkat dari kaki kanan dan lembing sudah dapat dilemparkan. Sedangkan gaya langkah silang memiliki teknik gerakan lebih sulit karena memiliki langkah silang berkalikali dan menjaga agar tidak kehilangan kecepatan awalan untuk menghasilkan gaya tersebut maka diperlukan latihan yang teratur, dan metode pembelajaran yang tepat.
Perlu disadari bahwa munculnya atlet berprestasi tinggi tidaklah beralur tunggal, semata-mata ditentukan oleh potensi yang ada pada diri atlet sendiri, melainkan juga dipengaruhi oleh faktor lingkungan dimana potensi atlet diaktualisasikan. Menurut Gould, Dieffenbach dan Moffett (2002) yang dikutip oleh Mutohir dan Maksum (2007) menyatakan ada 3 lingkungan utama dimana atlet umumnya berkembang yaitu : 1) lingkungan keluarga, 2) lingkungan sekolah dan 3) lingkungan olahraga. Di lingkungan sekolah, pengaruh bisa datang dari guru pendidikan jasmani dan kegiatan olahraga di sekolah. Menurut Bomba (1990:334), perkembangan atlet juga dipengaruhi oleh bakat, bakat itu sendiri dapat diidentifikasi melalui seleksi alam dan seleksi 
ilmiah. Seleksi alam merupakan pendekatan yang normal, seleksi ini menganggap bahwa atlet mengikuti olahraga tertentu sebagai hasil dari pengaruh setempat, misalnya tradisi sekolah, harapan orang tua dan teman sebaya.

Seleksi ilmiah adalah metode ilmiah yang digunakan untuk memilih calon atlet yang perlu dibina.

Selanjutnya Mutohir dan Maksum (2007) menyatakan, bahwa prestasi puncak adalah hasil dari seluruh usaha program pembinaan jangka tertentu, yang pada hakikatnya bahwa prestasi yang dicapai seseorang atlet merupakan paduan akhir dari proses latihan yang dirancang secara sistematik, berjenjang, berkesinambungan, berulang-ulang makin lama makin meningkat.

Menurut guru pendidikan jasmani SMP

Negeri 1 Porsea, nilai prestasi belajar siswa yang belum memuaskan, itu disebabkan nilai praktek atau keterampilan mereka masih relatif rendah. Memang penguasaan teknik-teknik dasar disetiap cabang olahraga memerlukan motivasi belajar dan kecermatan yang tinggi. Untuk lempar lembing misalnya siswa harus menguasai beberapa macam teknik dasar. Menurut IAAF (1993: 116-119), teknik-teknik dasar yang harus dipahami dalam lempar lembing adalah: (1) Awalan, (2) Tahap transisi/ perpindahan, (3) Tahap akhir, (4) Lemparan. Sesuai dengan sistim energi yang dibutuhkan unsur yang paling dominan adalah power lengan. Ini terlihat pada saat gerakan melempar lembing, membutuhkan unsur power lengan .

Selain itu, hasil belajar lempar lembing yang belum memuaskan dapat disebabkan metode pembelajaran yang kurang efektif. Metode pembelajaran yang biasa digunakan guru pendidikan jasmani di sekolah, yaitu dengan memberi penjelasan kemudian siswa disuruh untuk melatihkannya, dinilai kurang menarik perhatian siswa karena siswa kurang dituntut kreatifitasnya. Hal ini sejalan dengan pendapat Trianto (2007) yang menyatakan, prestasi belajar peserta didik merupakan hasil kondisi pembelajaran yang masih bersifat konvensional dan tidak menyentuh ranah dimensi peserta didik itu sendiri tentang bagaimana sebenarnya belajar itu.

Belajar motorik terdiri dari 2 kata yaitu belajar dan motorik. Belajar dapat dinyatakan sebagai perubahan internal individu yang disimpulkan dari perkembangan prestasinya yang relatif stabil, sebagai hasil latihan sedangkan motorik menunjukkan keadaan / sifat bentuk apa yang telah dihasilkan dalam proses latihan. Singer (1982) menyatakan, belajar motorik adalah suatu perubahan sikap, jenis kelamin, usia. Sedangkan Schmidt (1988) menyatakan belajar motorik adalah proses perubahan atau modifikasi individu sebagai hasil timbal balik antara latihan dan pengalaman. Sejalan dengan itu Drowatzky (1981) menyatakan bahwa belajar motorik adalah proses perubahan atau modifikasi individu sebagai hasil timbal balik antara latihan dan kondisi lingkungan. Dari keterangan singkat di atas dapat dinyatakan bahwa belajar motorik adalah perubahan internal dalam bentuk gerak (motor) yang dimiliki individu yang disimpulkan dari perkembangan prestasi yang relatif permanen dan ini semua merupakan hasil dari suatu latihan .

Tujuan akhir dari belajar keterampilan motorik adalah kemampuan untuk memperagakan keterampilan secara otomatis. Dengan demikian dapatlah dikatakan bahwa sejajar keterampilan motorik itu pada hakekatnya merupakan pembentukan antara stimulus dan respon motorik.

Pembelajaran keterampilan menyangkut faktor kesiapan belajar dan faktor kesiapan fisik. Lutan (1988) menyatakan kesiapan fisik dalam keterampilan motorik dibagi tiga yaitu (1) kematangan, (2) perkembangan motorik umum, dan (3) keterampilan prasyarat. Kematangan berarti perkembangan fisiologis, seperti ukuran besar, bentuk yang terjadi sebelumnya yang meningkatkan kapabilitas motorik individu untuk mempelajari keterampilan gerak. Perkembangan motorik adalah penyempurnaan kemampuan motorik (kekuatan, koordinasi, kecepatan, keseimbangan dan agilitas) sebagai keseimbangan dalam latihan. Keterampilan prasyarat dapat pula dikatakan sebagai gerakangerakan dasar bagi keterampilan yang lebih tinggi.

Melempar merupakan proses gerak seseorang melakukan gerakan terhadap suatu benda agar benda tersebut dapat dipindahkan sejauh mungkin. Sedangkan lembing merupakan suatu benda yang terdiri dari mata lembing, badan lembing dan tali pegangan lembing. Mata lembing terbuat dari metal, badan lembing terbuat dari kayu atau metal. Badan lembing yang terbuat dari kayu dapat digunakan dalam perlombaan internasional atau perlombaan resmi lainnya.

Sedangkan untuk mata pelajaran atau pendidikan dapat digunakan yang dari bambu. Tali lembing terletak melilit pada bagian tengah 
pada titik pusat lembing. Unsur gerak dan tujuan dari proses gerakan menjadi bagian dari kegiatan melempar. Kedua hal tersebut merupakan kesatuan utuh dan berupa gerakan yang sering disebut teknik melempar lembing, yang selanjudnya diungkapkan dalam teknik lempar lembing.

Dalam lempar lembing pada prinsipnya terjadi gerakan. Menurut Soedarminto (1992:16) gerakan dalam lembing adalah gerak lurus dan gerak berputar. Dalam gerak lurus gerakan mendorong sangat menonjol, sedangkan pada gerak berputar daya tarik sangat menonjol. Kedua gerakan tersebut sangat berpengaruh terhadap hasil lemparan. Kemampuan seorang atlit dalam melempar lembing dipengaruhi oleh faktor eksternal yang berupa lapangan lembing dan alat lembing yang digunakan

Engkos Kosasih (1984:66) mengemukakan bahwa "Pada nomor lempar lembing diperlukan suatu awalan, seperti pada nomor lompat, jadi pada nomor lempar itu dipergunakan kecepatan dan perpaduan tenaga pada saat melempar". Sedangkan pendapat Jess Jarver (1986:138) mengatakan "Untuk mendapatkan kecepatan yang maksimal dalam lempar atlit hendaknya berlari terlebih dahulu dalam jarak yang tanpa batas, sebelum sampai pada posisi untuk melempar". Berdasarkan dua pendapat di atas, untuk mendapatkan prestasi yang maksimal, lempar lembing harus harus dilakukan dengan kecepatan yang tinggi dan kekuatan pada saat melempar.

Dalam nomor lempar lembing, ada dua macam gaya yang dapat digunakan, yaitu gaya hop dan gaya cross. Disini akan dikemukakan salah satu gaya yaitu gaya cross/silang. Gaya ini banyak digunakan oleh atlit-atlit nasional, proses pelaksanaannya tidak mengurangi kecepatan saat melakukan awalan lempar. Dari segi efektivitas gaya cross lebih menguntungkan walaupun teknik melakukannya lebih sulit. Adapun teknik langkah gaya cross menurut Soegito (1991:81) sebagai berikut:

\section{Awalan}

(a) Panjang awalan 16 langkah terbagi dalam 3 bagian. 7 langkah sebagai awalan, 6 langkah dengan 3/4 kecepatannya dan 6 langkah untuk persiapan dan pelaksanaan gerakan lempar (pedoman ini tidak bersifat lempar mutlak, didasarkan pada kemampuan masing-masing yang penting pembagian kecepatan awalan tersebut tetap sama). (b) Gerakan dimulai dengan melangkahkan kaki kanan. Dalam membawa lembing gerakan tangan tidak kaku, mata lembing mengarah serong ke atas.

(c) Pada langkah ke 7 kaki kanan sampai pada tanda ke dua, larinya dipercepat sampai $3 / 4$ kecepatannya.

(d) Langkah ke 13 kaki kanan sampai pada tanda ke tiga. Begitu kaki kanan mendarat dilakukan langkah silang oleh kaki kanan tersebut. Ujung kaki mendarat serong ke kanan. Sikap gerak ini merupakan langkah pertama persiapan melempar.

\section{Sikap melempar}

(a) Begitu kaki kanan mendarat, tangan yang membawa ke belakang, kaki kiri dilangkahkan jauh ke depan.

(b) Badan diputar ke kanan bersamaan dengan gerakan lembing ke belakang.

(c) Kaki kanan dilangkahkan ke depan merupakan langkah untuk melakukan lemparan.

\section{Teknik lempar}

(a) Mata melihat dengan mantap ke sasaran.

(b) Lembing diangkat ke atas, siku dibengkokkan sedikit.

(c) Badan tengadah membentuk busur tegangan, efisien dalam penggunaan tenaga.

Metode adalah cara atau upaya yang dilakukan untuk mencapai sasaran tertentu. Soekamto (1996: 151) "Metode atau strategi adalah keseluruhan prosedur yang sistematis untuk mencapai tujuan". Sedangkan menurut Winarno Surahmat (1982:131) metode adalah "cara yang sebaik-baiknya untuk mencapai tujuan".

Selanjutnya pembelajaran secara umum dapat diartikan dengan perihal membuat siswa melakukan perbuatan belajar. Senada dengan itu Sagala (2007) menyatakan, pembelajaran mengandung arti setiap kegiatan yang dirancang untuk membantu seseorang mempelajari suatu kemampuan atau nilai yang baru.

Menurut Miarso (2004) bahwa pembelajaran yang disebut juga kegiatan pembelajaran atau intruksional adalah usaha mengelolah lingkungan dengan sengaja agar seseorang membentuk diri secara positif tertentu dalam kondisi tertentu. Dan suatu program pembelajaran yang baik haruslah memiliki kriteria daya tarik, daya guna (efektivitas) dan hasil guna (efisiensi).

Dimyati (2010:297) mengatakan pembelajaran adalah kegiatan guru secara terprogram dalam 
desain instruksional,untuk membuat siswa secara aktif, yang menekankan pada penyediaan sumber belajar.

Sedangkan Majid (2006) mengatakan bahwa kegiatan pembelajaran diarahkan untuk memberdayakan semua potensi peserta didik untuk menguasai potensi yang diharapkan, kemudian ditambahkan bahwa kegiatan pembelajaran mengembangkan kemampuan untuk mengetahui, memahami, melakukan sesuatu, hidup dalam kebersamaan dan mengaktualisasikan diri.

Hamalik (2007) mengatakan bahwa pembelajaran adalah suatu kombinasi yang tersusun meliputi unsur-unsur manusiawi, material, fasilitas, perlengkapan, dan prosedur yang saling mempengaruhi mencapai tujuan pembelajaran yang terdiri dari siswa, guru, dan tenaga lainnya, misalnya tenaga laboratorium. Sedangkan material meliputi buku-buku, papan tulis dan kapur, fotografi, slide dan film, audio dan vidio tape. Fasilitas dan perlengkapan terdiri dari ruangan kelas, perlengkapan audiovisual juga komputer. Dan prosedur mengikuti jadwal dan metode penyampaian informasi, praktik, belajar, ujian dan sebagainya.

Reigeluth (1993) menyatakan bahwa metode pembelajaran adalah suatu cara untuk mencapai hasil yang baik pada situasi yang berbeda. Dalam hal ini guru sebagai tenaga perancang pembelajaran (instruksional designer) harus mampu memanipulasi situasi, atau keadaan, cara sehingga menjadi suatu suasana yang menarik.

Suparman (1995) mendefinisikan, metode pembelajaran adalah berbagai perpaduan dari 1) urutan kegiatan instruksional, 2) cara pengorganisasian materi pengajaran dan peserta belajar, peralatan dan bahan, 4) waktu yang digunakan dalam proses instruksional. Sejalan dengan itu Seel and Richey (1994:129) pengurutan kegiatan dalam suatu pengajaran tertentu.

Bermain adalah suatu kegiatan yang dilakukan dengan dan tanpa mempergunakan alat yang menghasilkan pengertian atau memberikan informasi, memberikan kesenangan maupun imajinasi kepada anak. Tedjasaputra (2005) menyatakan bermain merupakan suatu yang penting bagi anak. Melalui bermain anak mengenal dunianya. Seni rupa, seni tari, seni musik dan drama merupakan kegiatan bermain bagi anak sekaligus untuk lebih mengenal dunianya. Sebagai contoh dengan kegiatan seni musik anak dapat bernyanyi, memainkan alat musik, mengikuti irama seperti mengikuti rime dan tempo lewat tepuk tangan, melakukan gerakangerakan dan berpantun.

Lutan (1988) menyatakan bermain merupakan aktivitas yang disenangi dan memiliki pengaruh terhadap kehidupan dan bermain merupakan kebutuhan yang hakiki bagi manusia. Senada dengan hal itu Singer berpendapat seperti yang dikutip oleh Tedjasaputra (2005) bahwa bermain memberikan suatu cara bagi anak untuk meningkatkan kecepatan masuknya perangsangan (stimulasi), baik dari dunia luar maupun dari dalam, yaitu aktifitas otak yang secara konstan memainkan kembali dan merekam pengalaman-pengalaman. Hal ini berarti bahwa melalui bermain, anak dapat mengoptimalkan laju stimulasi dari luar dan dari dalam sehingga ia mengalami emosi yang menyenangkan dan tidak "bengong" sekalipun terlalu banyak stimulasi dan tidak bosan sekalipun stimulasi relatif sedikit.

Menurut Brunner yang dikutip oleh Tedjasaputra (2005), fungsi bermain adalah sebagai sarana mengembangkan kreativitas dan fleksibilitas. Dalam bermain yang lebih penting bagi anak adalah makna bermain dan bukan hasil akhirnya. Artinya, saat anak bermain, anak tidak memikirkan sasaran yang akan dicapai sehingga dia mampu bereksperimen dan memadukan berbagai prilaku baru yang tidak biasa.

Gunawan (2004) berpendapat bahwa ketika bermain sambil belajar, dapat mempersingkat waktu hingga 60 persen. Hal ini dibuktikan dengan cara mengkonversi matapelajaran ekonomi ke dalam modalitas cara belajar dipercepat (genius learning). Dengan memodivikasi materi-materi tadi kedalam satu tema, kemudian mengelompokkan siswa yang masing-masing mendapat tugas membawa makanan dan minuman yang ditentukan untuk menciptakan bermain pasar-pasaran. Memang dalam waktu yang singkat sub-sub materi dalam pelajaran ekonomi yang dimasukkan ke dalam satu tema dapat dipahami oleh siswa. Kemudian Meier (2005) menyatakan terkadang bermain bisa menarik, cerdik menyenangkan, dan sangat memikat, namun tidak memberi hasil penting pada pelajaran. Jika demikian, itu hanya membuang-buang waktu dan segera ditinggalkan. Dengan kata lain, jika permainan menghasikan peningkatan dalam pembelajaran dan prestasi kerja sangat baik digunakan, tetapi jika tidak, tinggalkan. 
Langkah-langkah pembelajaran dengan menggunakan metode bermain adalah sebagai berikut:

- Guru membuka pelajaran dan mengimformasikan tujuan pembelajaran yang akan dicapai.

- Guru membagi siswa dalam beberapa kelompok dan masing-masing kelompok mendapat tugas dalam menyelesaikan tugas gerak yang akan di capai.

- Guru menjelaskan tujuan gerak yang akan di capai dan memberi contoh gerakan.

- Guru memberi kesempatan kepada setiap kelompok untuk melaksanakan secara keseluruhan gerakan yang akan dicapai.

- Guru mengarahkan atau mengawasi siswa dalam pelaksanaannya, kemudian diberi kebebasan mengulang-ulang sampai siswa mampu menguasai gerakan.

Menurut Sanjaya (2008), metode demonstrasi adalah metode penyajian pelajaran dengan memperagakan dan mempertunjukkan kepada siswa tentang suatu proses, situasi atau benda tertentu, baik sebenarnya atau hanya sekedar tiruan. Senada dengan hal itu, Sabri (2005) menyatakan, metode demonstrasi adalah suatu metode mengajar yang memperlihatkan bagaimana proses terjadinya sesuatu. Hal ini dapat dilakukan oleh guru atau orang lain yang sengaja diminta dalam suatu proses. Masih diperkuat oleh Sumiari dan Asra (2009:101) mengatakan, metode demonstrasi adalah pertunjukan atau peragaan dalam pembelajaran sebagai suatu proses yang dilakukan oleh guru berkenaan dengan materi pembelajaran.

Metode demonstrasi merupakan salah satu bentuk pembelajaran dari sekian banyak bentuk pembelajaran yang ada, yang akan membantu seseorang guru/pembina untuk memperlihatkan proses terjadinya suatu peristiwa/sesuatu warna, bentuk atau penampilan tingkah laku, karena demonstrasi adalah petunjuk tentang proses terjadinya suatu peristiwa atau benda sampai pada penampilan tingkah laku yang dicontohkan agar dapat diketahui dan dipahami secara nyata atau tiruannya.

Dimyati dan mudjiono (2010) menyatakan, metode demonstrasi adalah suatu metode sederhana yang sering digunakan oleh guru dalam kegiatan belajar mengajar dengan menunjukkan dan memeragakan keterampilan fisik atau kegiatan lain. Sejalan dengan hal itu, Sanjaya (2008) menyatakan, metode demontrasi sebagai cara penyajian pelajaran dengan memperagakan dan menunjukkan kepada peserta didik suatu proses, situasi atau benda tertentu yang sedang dipelajari, baik dalam bentuk sebenarnya maupun bentuk tiruan yang dipertunjukkan oleh guru atau sumber belajar lain yang memahami atau ahli dalam topik bahasan yang harus didemonstrasikan .

Menurut Hasibuan dan Mudjiono (2008), demontrasi sebagai metode mengajar adalah bahwa seorang guru atau seorang demonstrator (orang luar yang sengaja diminta) atau seorang siswa memperlihatkan kepada seluruh kelas suatu proses. Selanjudnya Djamarah dan Zain (2002) menyatakan , metode demonstrasi adalah cara penyajian bahan pembelajaran dengan meragakan atau mempertunjukkan kepada siswa suatu proses, situasi atau benda tertentu yang sedang dipelajari, baik yang sebenarnya maupun tiruan, yang sering disertai dengan penjelasan lisan.

Berdasarkan pendapat para ahli di atas dapat disimpulkan bahwa metode demonstrasi adalah suatu metode pembelajaran untuk menyajikan bahan pembelajaran dengan menunjukkan atau memeragakan suatu proses, situasi atau benda, baik yang sebenarnya ataupun tiruan, yang biasanya disertai dengan penjelasan.

Dalam konteks pembelajaran lempar lembing, metode demonstrasi dapat diartikan dengan metode latihan yang dikembangkan untuk setiap pertemuan dan dalam penggunaannya selalu disesuaikan dengan cara atau contoh yang diberikan oleh guru atau model. Dengan metode demonstrasi ini, siswa dituntut untuk selalu berkonsentrasi pada setiap gerak-gerik yang dipertunjukkan oleh seorang guru atau model.

Langkah-langkah pembelajaran dengan menggunakan metode demonstrasi adalah sebagai berikut:

- Guru membuka pelajaran dan merumuskan tujuan pembelajaran yang akan dipelajari.

- Guru menjelaskan tujuan gerak yang akan dicapai dan memberi contoh gerakan serta mendemonstrasikan gerakannya.

- Guru secara bagian-bagian menentukan tugas gerak yang harus dilakukan siswa secara frekwensi pengulangan gerakannya.

- Guru mengontrol atau mengawasi secara ketat dari pada pelaksanaan tugas yang telah diberikan kepada siswa.

- Guru memberikan feed back atas pekerjaan siswa secara keseluruhan ketika ada 
kesalahan atau kebaikan yang dilakukan siswa.

Berdasarkan uraian diatas tentang metode bermain dan metode demonstrasi maka perbedaan kedua macam metode ini dapat digambarkan seperti dalam tabel. 1 berikut ini.

Tabel 1. Perbedaan Karakteristik Metode Pembelajaran

\begin{tabular}{|c|c|}
\hline \multicolumn{2}{|c|}{ Metode Pembelajaran } \\
\hline Metode Bermain & Metode demonstrasi \\
\hline $\begin{array}{l}\text { Materi atau bahan ajar disajikan secara } \\
\text { keseluruhan dan mengimformasikan tujuan } \\
\text { pembelajaran serta memotivasi siswa. }\end{array}$ & $\begin{array}{l}\text { Materi dan bahan ajar disajikan secara sebagian } \\
\text { dan merumuskan tujuan pembelajaran yang akan } \\
\text { dicapai. }\end{array}$ \\
\hline $\begin{array}{l}\text { Materi dan bahan ajar disajikan dalam bentuk } \\
\text { berbagai tingkat kesulitan, guru memberi } \\
\text { contoh gerakan melalui gambar-gambar. }\end{array}$ & $\begin{array}{l}\text { Materi atau bahan ajar disajikan dengan tingkat } \\
\text { kesulitan paling rendah guru } \\
\text { mendemonstrasikan gerakan yang akan dicapai. }\end{array}$ \\
\hline $\begin{array}{l}\text { Siswa dibagi dalam beberapa kelompokdan } \\
\text { tiap kelompok melaksanakan tugas gerak } \\
\text { yang akan dicapai dengan bebas. }\end{array}$ & $\begin{array}{l}\text { Siswa melaksanakan tugas gerak sesuai dengan } \\
\text { gerakan yang dibuat guru secara bergiliran. }\end{array}$ \\
\hline $\begin{array}{l}\text { Seluruh siswa aktif bergerak dalam } \\
\text { kelompoknya untuk melaksanakan } \\
\text { gerak, bersifat kompetitif }\end{array}$ & $\begin{array}{l}\text { Siswa yang aktif adalah siswa yang mendapat } \\
\text { giliran untuk melaksanakan tugas gerak tidak } \\
\text { kompetitif. }\end{array}$ \\
\hline $\begin{array}{l}\text { Siswa dibiasakan menghadapi situasi seperti } \\
\text { dalam situasi permainan sebenarnya, } \\
\text { membina kerjasama dan kegagalan dalam } \\
\text { melakukan tugas gerak dapat menghambat } \\
\text { aktifitas teman sekelompok. }\end{array}$ & $\begin{array}{l}\text { Siswa tidak dibiasakan menghadapi situasi } \\
\text { permainan, tanpa menuntut kerja sama dan } \\
\text { kegagalan dalam tugas gerak tidak merugikan } \\
\text { siswa lainnya. }\end{array}$ \\
\hline $\begin{array}{l}\text { Siswa diberi kebebasan mengulang gerakan } \\
\text { pada tingkat kesulitan dalam setiap } \\
\text { pertemuan. }\end{array}$ & $\begin{array}{l}\text { Siswa mengulang gerakan sesuai dengan apa } \\
\text { yang telah ditentukan oleh guru dalam setiap } \\
\text { pertemuan. }\end{array}$ \\
\hline $\begin{array}{l}\text { Guru mengawasi dan mengontrol siswa } \\
\text { dalam melaksanakan tugas gerak dan } \\
\text { mengevaluasi serta memberikan umpan balik } \\
\text { terhadap siswa secara individu atau } \\
\text { kelompok. }\end{array}$ & $\begin{array}{l}\text { Guru memperhatikan siswa dalam pelaksanaan } \\
\text { tugas gerak dan mengevaluasi, kemudian } \\
\text { memberikan umpan balik terhadap siswa secara } \\
\text { menyeluruh. }\end{array}$ \\
\hline
\end{tabular}

Belajar merupakan hal yang kompleks. Kompleksitas berbagai proses, belajar tersebut dapat dipandang dari dua subyek, siswa dan guru. Dari segi siswa, belajar dialami sebagai suatu proses, yakni proses mental dalam menghadapi bahan belajar yang berupa keadaan, hewan, tumbuhan, manusia, dan bahan yang telah terhimpun dalam buku pelajaran. Dari segi guru proses belajar tampak sebagai perilaku belajar tentang suatu hal.

Belajar merupakan proses internal yang melibatkan ranah-ranah kognitif, afektif, dan psikomotorik. Dalam pembelajaran olahraga lebih dominan adalah ranah psikomotorik yang menurut Simson terdiri dari tujuh jenis perilaku yaitu:

(1) Persepsi, yang mencakup memilahmilahkan (mendeskriminasikan) hal-halhal secara khas, dan menyadari adanya perbedaan yang khas tersebut. Misalnya, pemilihan warna, angka 6 (enam) dan 9 (sembilan), huruf $b$ dan $d$.

(2) Kesiapan, yang mencakup penempatan diri dalam keadaan di mana akan terjadi suatu gerakan atau rangkaian gerakan. Kemampuan ini mencakup jasmani dan rohani. Misalnya posisi start lomba lari.

(3) Gerakan terbimbing, mencakup kemampuan melakukan gerakan sesuai contoh, atau gerakan peniruan. Misalnya meniru gerak tari, membuat gerakan di atas pola.

(4) Gerakan yang terbiasa, mencakup kemampuan gerakan-gerakan tanpa contoh. Misalnya melakukan lompat tinggi dengan tepat.

(5) Gerakan kompleks yang mencakup kemampuan melakukan gerakan atau keterampilan yang terdiri dari banyak tahap, secara lancar, efisien, dan tepat. 
Misalnya bongkar pasang peralatan secara tepat.

(6) Penyesuaian pada gerakan, yang mencakup kemampuan mengadakan perubahan dan penyesuaian pola gerak-gerik dengan persyaratan khusus yang berlaku. Misalnya keterampilan bertanding.

(7) Kreativitas, kemampuan melahirkan pola gerak-gerak yang baru atas pola prakarsa sendiri. Misalnya, kemampuan membuat tari kreasi baru.

(Dimyati dan Mudjiono, 2010 : 31)

Menurut Bloom, Ranah psikomotorik adalah ranah yang berkaitan dengan keterampilan atau skill atau kemampuan bertindak setelah seseorang menerima pengalaman belajar tertentu. Ada enam tingkat keterampilan dalam ranah psikomotorik,yaitu :

1. Gerakan reflek (keterampilan pada gerakan yang tidak sadar)

2. Keterampilan pada gerakan-gerakan dasar

3. Kemampuan perseptual, termasuk di dalamnya membedakan fisual membedakan ouditif, motorik, dan lainlain

4. Kemampuan di bidang fisik, misalnya kekuatan, keharmonisandan lain-lain.

5. Gerakan-gerakan skill, mulai dari keterampilan sederhana sampai pada yang kompleks.

6. Kemampuan yang berkenaan dengan komunikasi nondecursive seperti gerakan ekspresif dan interpretatif.

Ranah psikomotorik berkenan dengan tujuantujuan pendidikan yaitu berkaitan dengan gerak fisik yang manipulatif

Power merupakan salah satu komponen biomotorik yang memiliki peranan yang besar, untuk meningkatkan prestasi olahraga dan sangat diperlukan dalam berbagai cabang olahraga. Seseorang yang ingin bermain baik dan berprestasi olahraga harus memiliki power yang baik. Kadang kala power disebut sebagai power eksplosif. Power menyangkut kekuatan dan kecepatan kontraksi otot dinamika dan eksplosif serta melibatkan pengeluaran power maksimal dalam durasi waktu yang pendek.

Fox dan Bower (1993:68) mendefinisikan power sebagai kemampuan seseorang untuk menampilkan kerja maksimal persatuan unit waktu. Suharno Hp (1993:33) mengartikan power sebagai "kemampuan otot atau sekolompok otot dalam mengatasi tahanan beban dengan kecepatan tinggi dalam satu gerakan yang utuh, yang dilakukan secara eksplosif dengan memadukan antara kekuatan dan kontraksi otot". Sementara M. Sajoto (1994:17) mengatakan power otot atau muscular power adalah kemampuan seseorang untuk melakukan kekuatan maksimum dengan usaha yang dilakukan dalam waktu yang sependek-pendeknya. Dalam hal ini telah dinyatakan bahwa power otot merupakan perkalian antara kekuatan dan kecepatan.

Melihat pendapat di atas diketahui bahwa pada dasarnya faktor utama power lengan adalah kekuatan dan kecepatan, disamping juga dipengaruhi oleh teknik dan koordinasi gerakan. Power lengan dapat ditingkatkan dengan memberikan latihan kecepatan dan koordinasi dari gerakan-gerakan yang dilakukan.

Power juga dipengaruhi oleh serabut otot yang dimiliki . Jenis serabut otot cepat dan serabur lambat. Menurut Sadoso Sumorsardjono (1994:15) Serabut otot cepat merupakan serabut otot putih sedangkan serabut otot lambat merupakan serabut otot merah. Jika jenis serabut otot yang dimiliki atlet cenderung memiliki serabut otot putih maka atlet tersebut berbakat untuk gerakan-gerakan yang memerlukan kemampuan fisik dengan waktu kontraksi pendek seperti kecepatan dan kekuatan . Sedangkan otot yang dimiliki atlet cenderung serabut merah, atlet tersebut berbakat untuk gerakan yang memerlukan kamampuan fisik dengan waktu kontraksi lama seperti daya tahan (endurance).

Penentu power adalah intensitas kontraksi otot. Intensitas kontraksi yang tinggi merupakan kecepatan pengerutan otot setelah mendapat rangsang dari saraf. Intensitas kontraksi ini bergantung kepada rekruitmen sebanyak mungkin "motor unit" serta volume otot. Kecuali itu, produksi kerja otot secara eksplosif menambah suatu unsur yang baru, yakni terciptanya hubungan antara otot dengan sistem saraf. Dengan demikian unsur penentu power lengan otot adalah kecepatan rangsang saraf, kecepatan kontraksi otot, produksi energi biokimia dan pertimbangan mekanik gerak.

Masalah dalam penelitian ini sebagai berikut: (1) Apakah hasil belajar lempar lembing siswa yang diajar dengan metode permainan lebih tinggi dari hasil belajar siswa yang diajar dengan metode demonstrasi?; (2) Apakah hasil belajar siswa yang memiliki power lengan kuat lebih tinggi dari hasil belajar siswa yang memiliki power lengan lemah?; dan (3) Apakah ada interaksi antara metode 
pembelajaran dan power lengan siswa terhadap hasil belajar lempar lembing?

\section{METODE}

Penelitian ini dilaksanakan di SMP Negeri 1 Porsea Jl gereja desa Patane 1 Porsea Kabupaten Toba Samosir. Dan SMP negeri 2 Porsea Kompleks Tanah lapang desa Patane 3 Kabupaten Toba Samosir.

Metode penelitian kuasi eksperimen (experimental research method) sebab kelas yang dipergunakan adalah kelas yang telah terbentuk. Dalam penelitian ini terdapat dua kelompok perlakuan yaitu satu kelompok sebagai kelas perlakuan metode pembelajaran bermain dan satu kelompok lagi sebagai kelas perlakuan metode pembelajaran demonstrasi. Dalam penelitian ini dicoba melihat perbedaan hasil belajar lempar lembing akibat memakai metode pembelajaran yang berbeda. Desain eksperimen faktorial 2 x 2 yang digambarkan pada tabel. 2 sebagai berikut:

Tabel 2. Rancangan Penelitian Kuasi eksperimen faktorial 2 x 2

\begin{tabular}{|c|c|c|}
\hline Metode Pembelajaran & $\begin{array}{c}\text { Metode Bermain } \\
\text { (A1) }\end{array}$ & $\begin{array}{c}\text { Metode Demonstrasi } \\
\text { (A2) }\end{array}$ \\
\hline Power lengan & $\mathrm{A}_{1} \mathrm{~B}_{1}$ & $\mathrm{~A}_{2} \mathrm{~B}_{1}$ \\
\hline Lemah (B 1) $(\mathrm{B}$ 2) & $\mathrm{A}_{1} \mathrm{~B}_{2}$ & $\mathrm{~A}_{2} \mathrm{~B}_{2}$ \\
\hline
\end{tabular}

Keterangan:

A1 = Metode Pembelajaran Bermain

A2 = Metode Pembelajaran Demonstrasi

$\mathrm{B} 1=$ Power Lengan kuat

$\mathrm{B} 2=$ Power Lengan lemah

$\mathrm{A}_{1} \mathrm{~B}_{1}=$ hasil belajar lempar lembing siswa yang diajarkan dengan metode pembelajaran bermain yang memiliki power lengan kuat

$\mathrm{A}_{2} \mathrm{~B}_{1}=$ hasil belajar lempar lembing siswa yang dibelajarkan dengan metode pembelajaran demonstrasi yang memiliki power lengan kuat

$\mathrm{A}_{1} \mathrm{~B}_{2}=$ hasil belajar lempar lembing siswa yang diajarkan dengan metode pembelajaran bermain yang memiliki power lengan lemah

$\mathrm{A}_{2} \mathrm{~B}_{2}=$ hasil belajar lempar lembing siswa yang diajarkan dengan metode pembelajaran demonstrasi yang memiliki power lengan lemah

Teknik analisis data yang digunakan adalah teknik statistik deskriptif dan inferensial. Teknik statistik deskriptif digunakan untuk menguji hipotesis penelitian. Teknik inferensial yang akan digunakan adalah analisa varians ANAVA dua jalur ( desain faktoral $2 \times 2$ ) dengan taraf signifikansi 0,05 persen. Sebelumnya uji persyaratan normalitas sembarang data kelompok subjek dengan menggunakan uji Liliefors dan uji homogenitas varians dengan uji Bartlett. Selanjutnya setelah perhitungan ANAVA dilakukan uji Scheffe untuk mengetahui bentuk interaksi antara metode pembelajaran dan power lengan terhadap hasil belajar lempar lembing. Uji Scheffe dilakukan apabila jumlah sampel (n) dari kedua kelompok perlakuan berbeda jumlahnya.

Adapun hipotesa statistik yang akan diuji adalah:

Hipotesa pertama

$\mathrm{H}_{0} \quad: \mu \mathrm{A}_{1}=\mu \mathrm{A}_{2}$

$\mathrm{H}_{\mathrm{a}} \quad: \mu \mathrm{A}_{1}>\mu \mathrm{A}_{2}$

Hipotesa kedua

$\mathrm{H}_{0} \quad: \mu \mathrm{B}_{1}=\mu \mathrm{B}_{2}$

$\mathrm{H}_{\mathrm{a}} \quad: \mu \mathrm{B}_{1}>\mu \mathrm{B}_{2}$

Hipotesa ke tiga

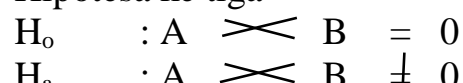

\section{HASIL DAN PEMBEHASAN}

Hasil

Hasil perhitungan data terhadap hasil belajar lempar lembing siswa diperoleh hargaharga sebagai berikut: skor tertinggi, skor terendah, rentang (range), skor rata-rata (mean), median (Me), modus (Mo) dan simpangan baku (s) serta jumlah data (n). Harga-harga dapat tersebut ditunjukkan pada Tabel 3.

Tabel 3. Ringkasan Deskripsi Data Hasil Penelitian 


\begin{tabular}{|c|c|c|c|c|c|c|c|c|}
\hline Statistik Dasar & $\mathbf{A}_{\mathbf{1}}$ & $\mathbf{A}_{\mathbf{2}}$ & $\mathbf{B}_{\mathbf{1}}$ & $\mathbf{B}_{\mathbf{2}}$ & $\mathbf{A}_{\mathbf{1}} \mathbf{B}_{\mathbf{1}}$ & $\mathbf{A}_{\mathbf{1}} \mathbf{B}_{\mathbf{2}}$ & $\mathbf{A}_{\mathbf{2}} \mathbf{B}_{\mathbf{1}}$ & $\mathbf{A}_{\mathbf{2}} \mathbf{B}_{\mathbf{2}}$ \\
\hline $\mathrm{n}$ & 35 & 37 & 35 & 37 & 17 & 18 & 18 & 19 \\
\hline Nilai Tertinggi & 16 & 15 & 16 & 15 & 16 & 15 & 15 & 15 \\
\hline Nilai Terendah & 7 & 7 & 8 & 7 & 10 & 7 & 7 & 7 \\
\hline Mean & 12,53 & 11,47 & 12,94 & 11,55 & 14,03 & 11,22 & 11,05 & 10,00 \\
\hline Median & 12,88 & 11,32 & 13,27 & 11,42 & 14,13 & 11,50 & 12,17 & 10,79 \\
\hline Modus & 13,41 & 12,35 & 13,83 & 11,70 & 14,25 & 11,83 & 12,83 & 11,50 \\
\hline Simpangan baku & 2,29 & 2,09 & 2,17 & 2,19 & 1,66 & 2,22 & 2,15 & 1,95 \\
\hline Varians & 5,26 & 4,35 & 4,73 & 4,77 & 2,76 & 4,93 & 4,61 & 3,81 \\
\hline
\end{tabular}

Untuk pengujian hipotesis penelitian digunakan statistik analisis varians (ANAVA) faktorial 2 x 2. Deskripsi data penelitian seperti ditunjukkan pada Tabel 4.

Tabel 4. Statistik Analisis Variansi Faktorial 2 X 2 Untuk Data Hasil Belajar Lempar Lembing Siswa

\begin{tabular}{|c|c|c|c|}
\hline Metode Pembelajaran (A) & $\begin{array}{l}\text { Bermain } \\
\left(\mathbf{A}_{1}\right)\end{array}$ & $\begin{array}{c}\text { Demonstrasi } \\
\left(\mathbf{A}_{2}\right)\end{array}$ & Total \\
\hline $\begin{array}{c}\text { Kuat } \\
\left(\mathbf{B}_{1}\right)\end{array}$ & $\begin{array}{c}\Sigma \mathrm{x}_{1}=236 \\
\mathrm{n}_{1}=17 \\
\bar{X}_{1}=14.03 \\
\mathrm{~s}_{1}=1.66\end{array}$ & $\begin{array}{c}\Sigma \mathrm{x}_{3}=213 \\
\mathrm{n}_{3}=18 \\
\bar{X}_{3}=11,22 \\
\mathrm{~s}_{3}=2.15\end{array}$ & $\begin{array}{c}\Sigma \mathrm{x}_{13}=449 \\
\mathrm{n}_{13}=35 \\
\bar{X}_{13}=12.62 \\
\mathrm{~s}_{13}=2.17\end{array}$ \\
\hline $\begin{array}{c}\text { Lemah } \\
\left(\mathbf{B}_{2}\right)\end{array}$ & $\begin{array}{c}\Sigma \mathrm{x}_{2}=202 \\
\mathrm{n}_{2}=18 \\
\bar{X}_{2}=11.05 \\
\mathrm{~s}{ }_{2}=2.22\end{array}$ & $\begin{array}{c}\Sigma \mathrm{x}_{4}=215 \\
\mathrm{n}_{4}=19 \\
\bar{X}_{4}=10,00 \\
\mathrm{~S}_{4}=1.95\end{array}$ & $\begin{array}{c}\Sigma \mathrm{x}_{24}=417 \\
\mathrm{n}_{24}=37 \\
\bar{X}_{24}=11.52 \\
\mathrm{~s}_{24}=2.19\end{array}$ \\
\hline Total & $\begin{array}{l}\Sigma \mathrm{x}_{12}=438 \\
\mathrm{n}_{12}=35 \\
\bar{X}_{12}=12.54 \\
\mathrm{~s}_{12}=2.29\end{array}$ & $\begin{array}{cc}\Sigma_{\mathrm{x}_{34}} & =428 \\
\mathrm{n}_{34} & =37 \\
\bar{X}_{34} & =10.61 \\
\mathrm{~s}_{34} & =2.09\end{array}$ & $\begin{array}{cc}\Sigma_{\mathrm{x}_{1234}}=866 \\
\mathrm{n}_{1234}=72 \\
\bar{X}_{1234}=11.75 \\
\mathrm{~s}_{1234}=2.19\end{array}$ \\
\hline
\end{tabular}

Selanjutnya perhitungan ANAVA faktorial 2 x 2 selengkapnya dapat dilihat pada lampiran. Ringkasan hasil penghitungan dari ANAVA seperti tercantum pada Tabel 5.

Tabel 5. Ringkasan ANAVA Faktorial 2 x 2

\begin{tabular}{|c|c|r|r|r|r|l|}
\hline Sumber Variansi & $\mathbf{d k}$ & \multicolumn{1}{|c|}{ JK } & RK & $\mathbf{F}_{\text {hitung }}$ & $\begin{array}{c}\mathbf{F}_{\text {tabel }} \\
(\mathbf{0 . 0 5})\end{array}$ & Keterangan \\
\hline Metode & 1 & 16.12 & 16.12 & 4.01 & 3.98 & signifikan \\
Pembelajaran & 1 & 43.68 & 43.68 & 10.86 & 3.98 & Signifikan \\
Power Lengan & 1 & 20.67 & 20.67 & 5.14 & 3.98 & Signifikan \\
Interaksi & 1 & 273.48 & 4.02 & & & \\
galat & 68 & 353.94 & & & & \\
\hline Total & 71 & & \\
\hline
\end{tabular}

Perhitungan uji Scheffe dapat dilihat pada lampiran. Hasil ringkasan perhitungan uji Scheffe ditabulasikan dalam Tabel 6.

Tabel 6. Ringkasan Hasil Perhitungan Uji Scheffe

\begin{tabular}{|l|c|c|}
\hline Hipotesis statistik & F $_{\text {hitung }}$ & $\mathbf{F}_{\text {tabel }} \boldsymbol{\alpha}=\mathbf{5 \%}$ \\
\hline
\end{tabular}




\begin{tabular}{|l|l|l|l|}
\hline Ho: $\mu \mathrm{A}_{1} \mathrm{~B}_{1}=\mu \mathrm{A}_{2} \mathrm{~B}_{1}$ & $\mathrm{Ha}: \mu \mathrm{A}_{1} \mathrm{~B}_{1}>\mu \mathrm{A}_{2} \mathrm{~B}_{1}$ & 4.14 & \\
Ho $: \mu \mathrm{A}_{1} \mathrm{~B}_{1}=\mu \mathrm{A}_{1} \mathrm{~B}_{2}$ & $\mathrm{Ha}: \mu \mathrm{A}_{1} \mathrm{~B}_{1}>\mu \mathrm{A}_{1} \mathrm{~B}_{2}$ & 3.07 & \\
Ho $: \mu \mathrm{A}_{1} \mathrm{~B}_{1}=\mu \mathrm{A}_{2} \mathrm{~B}_{2}$ & $\mathrm{Ha}: \mu \mathrm{A}_{1} \mathrm{~B}_{1}>\mu \mathrm{A}_{2} \mathrm{~B}_{2}$ & 4.05 & 2.74 \\
Ho $: \mu \mathrm{A}_{2} \mathrm{~B}_{1}=\mu \mathrm{A}_{1} \mathrm{~B}_{2}$ & $\mathrm{Ha}: \mu \mathrm{A}_{2} \mathrm{~B}_{1}>\mu \mathrm{A}_{1} \mathrm{~B}_{2}$ & 1.08 & \\
Ho $: \mu \mathrm{A}_{2} \mathrm{~B}_{1}=\mu \mathrm{A}_{2} \mathrm{~B}_{2}$ & $\mathrm{Ha}: \mu \mathrm{A}_{2} \mathrm{~B}_{1}>\mu \mathrm{A}_{2} \mathrm{~B}_{2}$ & 0.95 & \\
Ho $: \mu \mathrm{A}_{1} \mathrm{~B}_{2}=\mu \mathrm{A}_{2} \mathrm{~B}_{2}$ & $\mathrm{Ha}: \mu \mathrm{A}_{2} \mathrm{~B}_{2}>\mu \mathrm{A}_{1} \mathrm{~B}_{2}$ & 0.14 & \\
\hline
\end{tabular}

Secara keseluruhan hasil uji Scheffe menunjukkan dari enam kombinasi perbandingan rata-rata hasil belajar lempar lembing siswa (sesuai dengan desain ANAVA faktorial 2x2). maka tampak pada Tabel 6 yaitu tiga dari enam kombinasi menunjukkan hasil yang tidak signifikan.

Untuk hasil perhitungan rata-rata hasil belajar siswa yang diajarkan dengan metode bermain dan memiliki power lengan kuat (14.03) lebih tinggi dari pada rata-rata hasil belajar siswa yang diajarkan dengan metode demonstrasi dan memiliki power lengan kuat (11.94).

Untuk melihat interaksi antara metode bermain dan demonstrasi dengan kuat dan lemahnya power lengan siswa dapat dilihat pada Gambar 1.

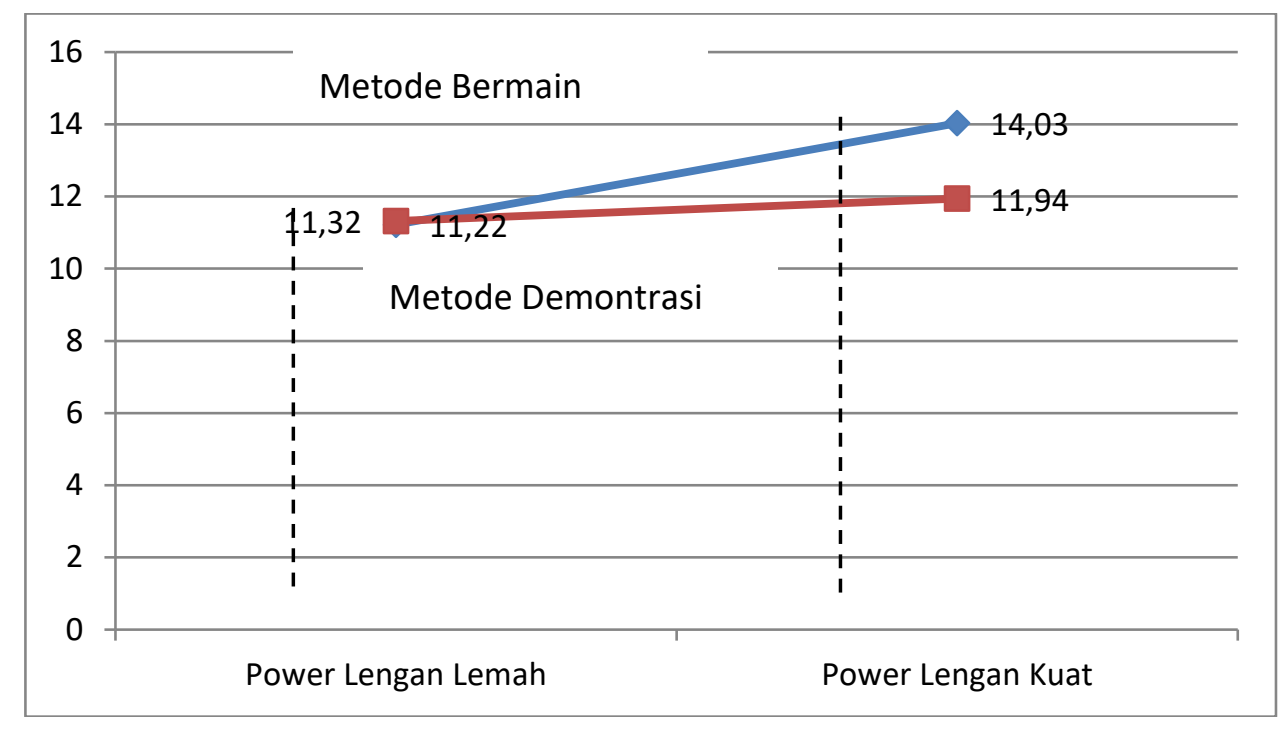

Gambar 1. Interaksi antara Metode Pembelajaran dan Power Lengan

\section{PEMBAHASAN}

Berdasarkan hasil-hasil perhitungan dalam penelitian yang diperoleh. terlihat bahwa belajar lempar lembing siswa yang diajarkan dengan metode bermain adalah lebih tinggi jika dibandingkan dengan hasil belajar lempar lembing siswa yang diajarkan dengan metode demonstrasi. Hal ini dimungkinkan karena dengan metode bermain siswa tidak merasa terbeban atau dipaksa dalam mempelajari gerakan. mereka diberi kebebasan untuk melakukan suatu gerakan dalam pembelajaran mereka lebih aktif.

Hal ini berarti bahwa melalui bermain. anak dapat mengoptimalkan laju stimulasi dari luar dan dari dalam sehingga ia mengalami emosi yang menyenangkan dan tidak "bengong" sekalipun terlalu banyak stimulasi dan tidak bosan sekalipun stimulasi relatif sedikit.
Dengan metode bermain juga akan membuka wawasan dan menjernihkan pendapat guru sehingga akan dapat lebih luwes terhadap kegiatan bermain itu sendiri. dan sebagai akibat bermain. itu akan mendukung segala aspek perkembangan anak. Maksudnya adalah guru dapat memberi kesempatan yang lebih banyak kepada siswa untuk berekplorasi sehingga pemahaman tentang konsep maupun pengertian dasar suatu pengetahuan dapat dipahami oleh siswa dengan lebih mudah.

Dalam penelitian ini telah menguatkan bahwa hasil belajar lempar lembing pada siswa yang diajar dengan metode bermain lebih tinggi secara signifikan dari hasil belajar lempar lembing siswa yang diajar dengan metode demonstrasi. Berdasarkan data yang diperoleh telah menunjukkan bahwa rata-rata hasil belajar lempar lembing siswa yang diajarkan dengan 
metode bermain (12.53) lebih tinggi dari pada rata-rata hasil belajar lempar lembing siswa yang diajarkan dengan metode demonstrasi (11.42).

Dari hasil rata-rata yang diperoleh telah menunjukkan bahwa hasil perbandingan ratarata hasil belajar lempar lembing siswa yang diajar dengan metode bermain lebih tinggi dari hasil belajar lempar lembing siswa yang diajar dengan metode demonstrasi. Hasil penelitian ini sesuai Pernyataan Pieget yang dikutip Tedjasaputra (2005) yang menyatakan bermain bukan saja dicerminkan tahap perkembangan kondisi itu sendiri. Pengetahuan akan konsepkonsep juga akan lebih mudah diperoleh melalui kegiatan bermain. Hal ini sesuai dengan dugaan sebelumnya yang mengunggulkan metode bermain dalam pembelajaran lempar lembing. Keunggulan dari metode bermain yang dipaparkan dalam kerangka berfikir terbukti secara empiris dilapangan. sehingga hasil ini telah menguatkan bahwa dengan metode bermain hasil belajar lempar lembing lebih baik.

Dalam mempelajari suatu gerak, keterampilan maupun melakukan suatu aktivitas setiap siswa berbeda-beda dalam melakukannya. Ada yang suka melakukan aktivitas-aktivitas dengan gerakan-gerakan yang bervariasi. Ada yang suka melakukan gerakan apabila diperintahkan guru dan menirukan apa yang dilakukan guru. Dalam lempar lembing misalnya tergantung power lengan yang dimiliki masing-masing siswa. Power merupakan salah satu komponen biomotorik yang memiliki peranan yang besar. untuk meningkatkan prestasi olahraga dan sangat diperlukan dalam berbagai cabang olahraga. Seseorang yang ingin bermain baik dan berprestasi olahraga harus memiliki power yang baik. Kadang kala power disebut sebagai power eksplosif. Power menyangkut kekuatan dan kecepatan kontraksi otot dinamika dan eksplosif serta melibatkan pengeluaran power maksimal dalam durasi waktu yang pendek.

Karena masing-masing siswa memiliki power lengan yang berbeda. seorang guru harus memiliki pengetahuan untuk mengajarkan suatu gerakan. sehingga guru merencanakan metode mengajar apa yang tepat yang akan disesuaikan dengan power lengan siswa.

Bagi siwa yang memiliki power lengan kuat akan suka dengan pengajaran yang tidak monoton. Pada umumnya siswa tersebut tidak bisa diam dan selalu aktif dan kreatif dalam mempelajari suatu gerakan. Sehingga diharapkan hasil belajar siswa yang memiliki power lengan kuat lebih tinggi daril hasil belajar siswa yang memiliki power lengan lemah. Hal ini terbukti secara empiris dilapangan bahwa hasil belajar lempar lembing siswa yang memiliki power lengan kuat lebih tinggi dari pada hasil belajar siswa yang memiliki power lengan lemah. Hasil temuan menunjukkan bahwa rata-rata hasil belajar lempar lembing yang memiliki power lengan kuat (14.03) lebih tinggi dari hasil belajar siswa yang memiliki power lengan lemah (11.32). Hal ini mendukung dari apa yang dinyatakan Buzan (2004) Anak yang secara fisik aktif juga bersikap lebih tenang dan penuh perhatian dan tampak lebih menikmati semua kegiatan. telah sesuai dengan temuan peneliti. Pada umumnya metode pembelajaran yang lebih mengaktifkan siswa untuk belajar membuahkan hasil belajar yang lebih tinggi. sesuai dengan penelitian yang relevan telah dinyatakan Hardinoto (2003) menemukan bahwa siswa yang diajar dengan permainan pembelajaran pendidikan jasmani memperoleh kemampuan gerak dasar yang lebih tinggi.

\section{PENUTUP \\ Simpulan}

Berdasarkan hasil pengolahan dan analisis data serta pengujian hipotesis maka dapat disimpulkan bahwa:

1. Hasil belajar lempar lembing siswa yang diajar dengan metode pembelajaran bermain lebih baik dibandingkan siswa yang diajar dengan metode pembelajaran demonstrasi.

2. Hasil belajar lempar lembing siswa yang memiliki power lengan kuat lebih baik dibandingkan siswa yang memiliki power lengan lemah.

3. Terdapat interaksi antara metode pembelajaran dan power lengan terhadap hasil belajar lempar lembing siswa. Untuk siswa yang memiliki power lengan tinggi lebih efektif dalam meningkatkan hasil belajar lempar lembing jika menggunakan metode bermain. sedangkan untuk siswa yang memiliki power lengan rendah lebih efektif dalam meningkatkan hasil belajar lempar lembing jika menggunakan metode demonstrasi.

\section{Saran}

Berdasarkan kesimpulan diatas maka saran yang diberikan adalah sebagai berikut : 
1. Untuk mengetahui power lengan siswa, disarankan kepada guru agar melakukan tes power lengan.

2. Bagi guru, metode bermain dapat dijadikan solusi dan alternatif metode pilihan yang dapat digunakan untuk meningkatkan hasil belajar lempar lembing siswa yang memiliki power lengan kuat yang efektif dan menarik, sedangkan metode demonstrasi cocok digunakan untuk siswa yang memiliki power lengan lemah.

3. Bagi sekolah. diharapkan dapat dijadikan sumbangan pemikiran dalam meningkatkan proses belajar mengajar pendidikan jasmani terutama dalam pembelajaran lempar lembing.

4. Sebagai rujukan dan gambaran bagi peneliti lain untuk mengadakan penelitian lanjutan.

\section{DAFTAR PUSTAKA}

Arma Abdoelah. (1981). Olahraga Untuk Perguruan Tinggi. Yogyakarta : PT. Santra Hudaya.

Bompa.O. (1994). Theory and Methodology of Training the Key to Athletic Performance. Dubuque. Iowa: Kendall.

Books George.A. and Thomas D. Fahey. (1984). Exercise Physiologis Human Bioenergetics and its Applications. New York: Jhon Willey.

Buzan. Tony.2004. Sepuluh Cara Jadi Orang Yang Bugar. Sehat dan Cerdas. Jakarta: Gramedia Pustaka Utama.

Dimyati dan Mujiono. (2010). Belajar dan Pembelajaran . Jakarta : Rineka Cipta.

Direktorat Olahraga Pelajar dan Mahasiswa. (2002). Seleksi dan Penelusuran Minat dan Bakat Olahraga . Jakarta : Departemen Pendidikan Nasional.

Djamarah. B.S. dan Zain. A. (2002). Strategi Belajar Mengajar. Jakarta : Rineka Cipta.

Drowatzky. J.N. (1981). Motor learning : Principleand practices. Minnepolis: Burgess Publishing Compeny.

Engkos Kosasih. (1984). Olahraga Teknik Dan Program Latihan. Jakarta: Akademika Prasindo.

Fox. E.L. Bowers. (1992). Sport . Philadelphia : WB. Sounders Company.

Gunawan. A.W. (2004). Genius Learning strategi. Jakarta : Gramedia.

Hamalik.O. (2007). Kurikulum dan Pembelajaran . Jakarta: Bumi Aksara.
Harsono. (1988) Coaching dan Aspek-Aspek Psikologi Dalam Coaching . Jakarta : Dirjen Dikti depdikbud.

Hutajulu. R. Pengaruh Metode Pembelajaran dan Gaya Belajar Terhadap Hasil Belajar Matematika Siswa SD di Kecamatan Pangaribuan. Tesis Tidak Diterbitkan. Pasca Sarjana Universitas Negeri Medan.

Irvan. (2006). Pengaruh Metode Latihan dan Koordinasi Terhadap Keterampilan Drive Tenis Meja. Tesis Tidak Diterbitkan. Surakarta. Program Pasca Sarjana Universitas Sebelas Maret.

Jess Jarver. (1986). Belajar Dan Berlatih Atletik. Bandung : Pionir Jaya.

Jonath U. Haag E. R. Krempel. (1987). Atletik 1. Alih Bahasa Duduque. IOWA: W.M.C Brown Publisher.

Lutan. R. (2001). Pembaruan Pendidikan Jasmani Di Indonesia. Jakarta : Direktorat Jenderal olahraga. Depdiknas.

Lutan. R. (1988). Belajar Keterampilan Motorik : Pengantar Teori dan Metode. Jakarta : Ditjen Dikti Depdikbud.

M. Furqon. H.(1995). Teori Umum Latihan. Terjemahan General Theory of Training. Josef Nossek. Surakarta : Sebelas Maret University Press.

Majid. A.(2006). Perencanaan Pembelajaran . Bandung : Remaja Rasdakarya.

Meier. D. (2005). The Accelarated Learning. Bandung : Mizan Pustaka.

Miarso. Y. (2007). Menyemai Benih Teknologi Pendidikan . Jakarta : Prenada Media.

Mujiono dan Hasibuan. J.J. (2008). Proses Belajar Mengajar. Bandung : Remaja Rosdakarya.

Mutohir. T.Ch.dan Maksum. A. (2007). Sport Developmen Indekx : Konsep. Metodologi.dan Aplikasi. Jakarta : Indeks.

Reigeluth.M. Charles. (1993). Intructional Design Theories and Models : An Overview of their current Status. New Jersey. London : publishers Hildshale.

Roji. (2006) . Pendidikan Jasmani Untuk SMP . Jakarta : Erlangga.

Sabri. A. (2005). Strategi Belajar Mangajar dan Micro Teaching. Jakarta : Quantum. Teaching.

Sadoso. Sumosardjuno. (1996). Sehat dan Bugar.Jakarta. Gramedia Pustaka Utama.

Sagala. S. (2007). Konsep dan Makna Pembelajaran. Bandung : Alfabeta. 
Sajoto.M. (1994). Peningkatan Dan Pembinaan Kekuatan Kondisi Fisik Dalam Olahraga. Semarang: Dahara Prize.

Sanjaya. S. (2008). Strategi Pembelajaran Berorientasi Strandar Proses Pendidikan. Jakarta: Kencana Pranada Media.

Singer. R.N. dan Dick. (1982). The learning of Motor Skill. New York: Macmillan Publishing.

Schmidt.R.A. (1988). Motor Control and Learning a Behaveor Emphasis. Champaign Illionis: Human Kinetic.

Soedarminto. (1992). Biomekanika Olahraga.Surakarta: UNS Press.

Soegito. (1991). Teori Dan Praktek Atletik II. Surakarta: UNS Press.
Sumiati \& Asra.(2009). Metode Pembelajaran. Bandung :Wacana Prima.

Sunjata.W \& Santosa teguh. (2010). Pendidikan Jasmani Olahraga dan Kesehatan. Jakarta: Pusat Buku kementrian nasional.

Suparman. A. (1995). Desain Instruksional. Jakarta : Direktorat Jendral Pendidikan Tinggi Depdikbud.

Surahmad. W. (1986). Pengantar Penelitian Ilmiah Dasar. Metodik dan Teknik. Bandung: Tarsito.

Tedjasaputra.M.S. (2005). Bermain. Mainan. dan Permainan.Jakarta : Grasindo.

Trianto. (2007). Model- Model Pembelajaran Inovatif Berorientasi Konstruktivistik. Jakarta : Prestasi Pustaka.

Wuryani. S.E.D. (2002). Psikologi Pendidikan. Jakarta : Gramedia. 